DOI: $10.17725 /$ rensit.2019.11.369

\title{
New additive technologies for forming complex bone structures for medical and biological applications
}

\section{Vladimir N. Gorshenev}

Emanuel Institute of Biochemical Physics of Russian Academy of Sciences, http://ibcp.chph.ras.ru/ Moscow 119334, Russian Federation

\section{Vladimir V. Kolesov}

Kotelnikov Institute of Radioengineering and Electronics of Russian Academy of Sciences, http:/ / cplire.ru/ Moscow 125009, Russian Federation

Mayya Yu. Ziangirova, Larisa M. Krasnopolskaya

Gause Institute of New Antibiotics, http:/ /www.gause-inst.ru/

Moscow 119021, Russian Federation

\section{Alexander A. Prosvirin}

Yevdokimov Moscow State University of Medicine and Dentistry, http://www.msmsu.ru

Moscow 127473, Russian Federation

\section{Andrei T. Teleshev}

Moscow Pedagogical State University, http://mpgu.su

Moscow 119001, Russian Federation

E-mail:gor@sky.chph.ras.ru,pchelka_mayya@mail.ru,kvv@cplire.ru,lmkrasnopolska@gmail.com,prosvirin@mail. ru,telesher@mail.ru

Received 30.09.2019, peer reviewed 14.10.2019, accepted 21.10.2019

Annotation. A synthesis of nanosized hydroxyapatite by the exchange reaction between diammonium phosphate and calcium nitrate under conditions of mechano-acoustic processing of the reaction mixture was developed. Methods are proposed for purifying hydroxyapatite from by-products. By dispersing raw materials of animal origin, a protein hydrosol was obtained in the medium of which hydroxyapatite was synthesized and a collagen-calcium-phosphate composite was obtained. Methods for the formation of porous collagen-calcium-phosphate composites, among which the effect of microwave radiation, are considered. It is shown that based on the developed biocompositions: calcium phosphate pastes, compositions from thermoplastic biodegradable polymers, non-woven fibrous materials, fabric-engineering constructions with an adjustable architecture can be made to solve various biomedical problems. The creation of three-dimensional structures capable of performing the functions of a particular natural tissue of the body, based on a combination of cells and scaffolds (three-dimensional structures, matrix, scaffold), as well as other factors affecting cell growth, their differentiation and organization of the extracellular matrix, is an important task of the tissue engineering.

Keywords: nanoscale hydroxyapatite, porous collagen-calcium-phosphate compounds, biodegradable polymers, non-woven fibrous materials, tissue engineering structures, $3 \mathrm{D}$ technologies

\section{UDC 615.46}

Acknowledgments: The work was carried out with the financial support of the Russian Federal Property Fund, project 18-29-23042.

For citation: Vladimir N. Gorshenev, Mayya Yu. Ziangirova, Vladimir V. Kolesov, Larisa M. Krasnopolskaya, Alexander A. Prosvirin, Andrey T. Teleshev. New additive technologies for forming complex bone structures for medical and biologocal applications. RENSIT, 2019, 11(3):369-390; DOI: 10.17725/ rensit.2019.11.369. 


\section{CONTENTS}

1. INTRODUCTION (370)

2. SyNthesis of CALCiUm phosphate COMPOUNDS TO COMBINE WITH THE COLLAGEN MATRIX (371)

3. The formation of COllagen-CalciumPHOSPHATE BIOCOMPOSITES (374)

4. The formation of porous materials BASED ON COLLAGEN-CALCIUM-PHOSPHATE COMPOSITIONS (375)

5. Production of fabric engineering STRUCTURES (379)

6. Methods of implanting POLyMER SAMPLES INTO A BONE DEFECT (383)

7. Production of bone substitute MATERIALS USING THE 3D PRINTING METHOD (384)

8. Conclusion (387)

REFERENCES (387)

\section{INTRODUCTION}

The problem of restoring the integrity of bones after their injuries and diseases is characterized by growing relevance and high socio-economic significance [1-3]. World clinical experience in the treatment of bone tissue pathology and replacement of bone defects constantly proves that the use of osteoplastic materials in reconstructive surgery is one of the decisive factors for achieving a positive result of the operation [4-7]. Tissue-engineering tasks for the development of complex designs of bonesubstituting materials can be solved with the joint participation of multidisciplinary teams of physicians, biologists, chemists, physicists and engineers. Substitution of bone tissue defects with porous implants followed by restoration of living bone tissue of the body should be considered as a process of realization of genetic information [8-10].

To develope optimal conditions for the regeneration of damaged tissue, knowledge of the mechanisms of regulation of its growth and differentiation is necessary. Knowledge about the process of osteogenesis, the processes of implant biodegradation in living systems, and the replacement of bone tissue defects contribute to the creation of new types of bone-replacing biomaterials when natural and synthetic polymers are mixed.

In modern implantology, it is fundamentally possible to distinguish several levels of technological developments in the manufacture of bioplastic bone materials [11]. The first donor level involves the use of donor tissues without their deep processing [12]. The second donor level is characterized by deep processing of donor tissue. An example is the manufacturing process of demineralized bone alloimplants, where the ratio of mineral and organic components is changed in bone tissue using decalcification with acid solutions. In such cases, the material acquires additional osteoinductive properties. In this case, bone demineralization can be superficial, partial or complete. Depending on the degree of decalcification, the material has different mechanical and plastic characteristics, which allows the surgeon to combine the material depending on the specific clinical situation [13].

The use of sterilization, viral inactivation using low-frequency ultrasound allowed to completely remove cellular elements, fat, bone marrow stroma, spongiosis [14]. The third level involves the creation of biocomposite materials containing both the main components of bone tissue and bioactive substances. Bioactive substances include growth factors, morphogenetic proteins and other components of the bone matrix, which play the role of activators and regulators of physiological tissue regeneration. Currently, the development of such biocomposite materials in Russia is becoming a priority $[15,16]$. The fourth technological level, which has been actively developed recently, determines the 
poPSibility of creating synthetic biocomposite materials based on modern technologies such as:

1. Stereolithographic copying of tissues [17].

2. Technologies for creating 3-dimensional implants $[18,19]$.

3. Liquid-distribution modeling [20].

4. Phase-changing creation of implants [21]. The combination of methods of the fourth technological level of bone engineering allows you to copy tissue objects with high accuracy and develope materials with clearly defined sizes, geometry and pore distribution, as well as fully reproduce the architectonics of the organ site and its internal channels in the implant being created.

When choosing the starting materials for forming biocomposites, collagen and hydroxyapatite are the most natural today, which in numerous animal experiments showed not only excellent biocompatibility, but also demonstrated their ability to stimulate bone formation and serve as a matrix for new bone tissue, depending on the composition, manufacturing method. However, when creating artificial collagen-apatite materials, the technological issues of regulating the porosity of the material, controlling the formation of its structure and mechanical strength remain far from solved. At that time, how exactly, these parameters are fundamentally important for the maximum manifestation of osteoconduction properties by the material during the reparative bone regeneration.

\section{SYNTHESIS OF CALCIUM PHOSPHATE COMPOUNDS TO COMBINE WITH THE COLLAGEN MATRIX}

A variety of biocompatible materials for clinical use as bone implants are being actively developed in world medical practice. At the same time, calcium phosphate compounds with natural polymers and biocompatible, biodegradable synthetic polymers are the main components in the production of bone implants. Works in the world practice on the production of bone implants is carried out in the following areas:

1) synthesis of calcium phosphate compounds;

2) the combination of calcium phosphate compounds with natural and / or synthetic polymers;

3) the synthesis of calcium phosphate compounds in gellike media of natural and synthetic polymers.

All conventionally identified areas are aimed at creating biocomposites to replace bone defects.

The first area related to the synthesis of calcium-phosphate compounds during the production of bone implants, the development of nanotechnology for their realization is still an urgent task. This is due to the fact that the corresponding synthetic calcium phosphate compounds should induce and actively participate in biological reactions similar to those occurring in the process of osteogenesis. The synthesis of solid calcium-phosphate particles for medical applications is usually carried out by precipitation from solutions [22]: For example, from solutions of 1) calcium nitrate and ammonium hydrogen phosphate, 2) calcium chloride and sodium hydrogen phosphate, 3) calcium chloride and potassium hydrogen phosphate, 4) calcium acetate and potassium hydrogen phosphate. Thus, in the manufacture of ceramic biocomposites, calcium phosphate was obtained from calcium acetate and sodium hydrogen phosphate [23].

In $[25,26]$, to obtain biocomposites, calcium phosphate powders were used, having nanoparticles of various phase compositions and forms, such as lamellar $0.8-4.5 \mathrm{~nm}$ thick 
and needle-like 5-10 $\mathrm{nm}$ in diameter, $40-50 \mathrm{~nm}$ long. It has been established that, depending on the synthesis conditions, phase composition, structural, morphological characteristics of calcium phosphate particles, its bioactivity can manifest itself in different ways. The possibility of modifying the surface of hydroxyapatite particles by radiation, chemical activation with the formation of radicals, and modification with chemical reagents and proteins has been established, which helps to strengthen the connection between the biocomposite and bone tissue.

This paper discusses the basics of energysaving technology for the production of calcium phosphate using hydroxyapatite as an example by mechano-acoustic activation of reaction mixtures consisting of:

1) aqueous suspensions of calcium monophosphate and calcium hydroxide;

2) from aqueous solutions of diammonium phosphate, calcium nitrate tetrahydrate and ammonium hydroxide.

Mechano-acoustic activation, under conditions of self-heating of the reaction mixture, was carried out using the rotarypulsation apparatus (RPA) "Delta-Rotor" (manufactured by "Aviatekhnika" Ltd.) [27], which allows the hydroxyapatite dispersion to be rapidly and completely formed in the aqueous medium.

The particle sizes of the dispersed phase were estimated using the dynamic light scattering method on a Zetasizer Nano ZS Zen 3600 Malvern instrument. The results of the distribution of the volume (mass) fraction of particles depending on their size indicate that in control syntheses, under standard laboratory conditions, the formation of rather large particles with an average hydrodynamic diameter of about $5.5 \mu \mathrm{m}$ takes place. In contrast, mechano-acoustic activation allows the formation of nanosized particles of hydroxyapatite having an average hydrodynamic diameter of about $20 \mathrm{~nm}$.

\subsection{SyNTHESIS OF "CONDENSATION" HYDROXYAPATITE}

The synthesis of "condensation" hydroxyapatite (HAP-c) was carried out according to the reaction equation

$6 \mathrm{CaHPO} \times \mathrm{H}_{2} \mathrm{O}+4 \mathrm{Ca}(\mathrm{OH})_{2} \rightarrow \mathrm{Ca}_{10}\left(\mathrm{PO}_{46}(\mathrm{OH})_{2}+12 \mathrm{H}_{2} \mathrm{O}\right.$

Changes in the ratio of the mass of reagents to the mass of the reaction medium, in the synthesis of HAP-c condensation method, slightly affect the particle size of the resulting dispersed phase. However, it should be noted that the width of the particle size distribution is certainly smaller at a low partial concentration of HAP-c. The specific features of the synthesis of HAP-c obtained by the interaction of calcium monophosphate and calcium hydroxide include the difficulty of controlling the reaction. This is largely due to the purity of the reagents and the accuracy of taking samples of the starting reagents. Express control in this case was carried out by changing the $\mathrm{pH}$ of the reaction medium or by sampling with their subsequent instrumental analysis, for example, using IR spectroscopy.

Hydroxyapatite (HAP-c) has a pronounced crystalline structure, which is confirmed by electron microscopy. Micrographs (Fig. 1) show lamellar crystals with powder inclusions.

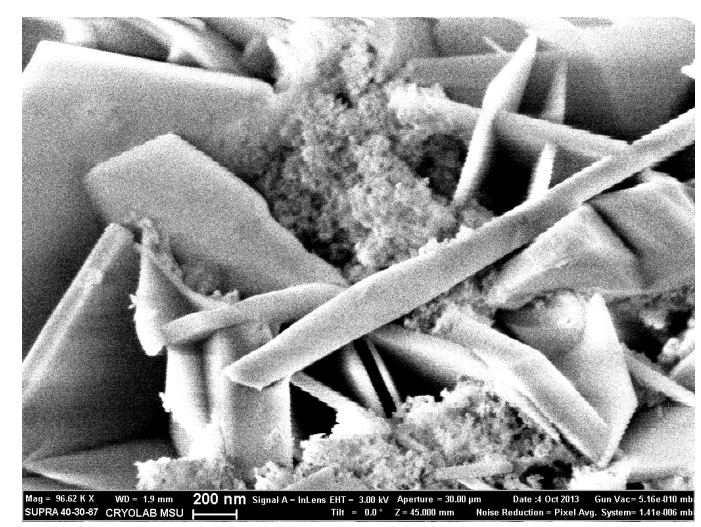

Fig. 1. Micrograph of particles (HAP-c). Scale-200 nm. Scanning electron microscope Neon 40 EsB-35-09. 


\subsection{SyNthesis of "ION-EXChANGE" HYDROXYAPATITE}

The synthesis of hydroxyapatite by the ion exchange reaction (HAP-i) was carried out according to the reaction equation:

$6\left(\mathrm{NH}_{4}\right)_{2} \mathrm{HPO}_{4}+10 \mathrm{Ca}\left(\mathrm{NO}_{3}\right)_{2} \times 4 \mathrm{H}_{2} \mathrm{O}+8 \mathrm{NH}_{4} \mathrm{OH} \rightarrow$ $\rightarrow \mathrm{Ca} 10\left(\mathrm{PO}_{4}\right)_{6}(\mathrm{OH})_{2}+20 \mathrm{NH}_{4} \mathrm{NO}_{3}+46 \mathrm{H}_{2} \mathrm{O}$

The particle sizes of the dispersed phase were estimated using the dynamic light scattering method. The results of the distribution of the volume (mass) fraction of particles depending on their size indicate that in the control synthesis (without using RPA), the formation of rather large particles with an average hydrodynamic diameter of about 5.5 $\mu \mathrm{m}$ takes place. In contrast, mechano-acoustic activation allows the formation of nanosized hydroxyapatite particles having an average hydrodynamic diameter of approximately $22 \mathrm{~nm}$. The maPS fraction of such particles in the reaction medium is $\approx 75 \%$. It should be noted that a decrease in the feed rate of the diammonium phosphate solution into the reactor and an increase in the rate of mixing of the reactants leads to an increase in dispersion. So, at a RPA rotor speed of $3100 \mathrm{rpm}$ and a rate of introduction of a diammonium phosphate solution of $0.51 /$ min into the reactor, a dispersion was obtained, characterized by particles having an average diameter of about $20 \mathrm{~nm}$. The maPS fraction of such particles in the reaction medium is $\approx 90 \%$.

The most energy-intensive part of the synthesis of HAP-i the exchange reaction is the purification of its sol from the by-product of ammonium nitrate. HAP-i nanoscale particles can only be separated from the liquid phase with great difficulty and freed from an admixture of ammonium nitrate. In this regard, the following options for obtaining pure HAP-i are implemented:

1) by decantation,

2) using centrifugation,
3) by heat treatment.

The second approach, in contrast to sedimentation in a gravitational field, allows you to increase the speed of the cleaning process. HAP-i cleaning by decantation is associated with high water consumption and cannot be considered effective. The interest is the heat treatment of the technical HAP-i, which was used in [28]. Indeed, we have shown that a HAP-i sample contaminated with ammonium nitrate can be successfully cleaned by heat treatment at $350^{\circ} \mathrm{C}$ for 30 minutes.

The data of elemental analysis, purified HAP-i confirm the complete absence of nitrogen-containing impurities in the heattreated sample (standard- ammonium nitrate). An additional confirmation of the absence of ammonium nitrate in the purified HAP-i samples is the results of the calorimetric experiment. HAP-i obtained by the exchange reaction and subjected to heat treatment, passes into a xerogel having characteristic blue luminescence.

It should be noted that the crystalline phase is not dominant in the structure of purified HAP-i. This is observed both for the sample of its suspension, and for the sample - xerogel. This is indicated by the data of electron scanning microscopy.

Using the method of reference contact porometry to determine the weight of a sample treated with octane under vacuum, it was found that the porosity of the heat-treated HAP- $\mathrm{i}$ is about $75 \%$ with an average pore radius of $2.8 \cdot 10^{3} \mathrm{~nm}$. HAP-i purified from impurities and dispersed in water, is prone to changes in its properties over time. These changes, in particular, are directed towards the enlargement of the particles of the dispersed phase. So, after holding the dispersion of purified HAP-i in an aqueous medium for 30 days, the average particle diameter increases to $44 \mathrm{~nm}$. The change in time of the dispersion 
of the HAP-i purified from byproducts of the reaction, may be due to: a change in the nature of the dispersion medium. In this case, the characteristic of the diffuse layer of counterions changes. This is indicated by the found drop in the zeta potential from $+30 \mathrm{mV}$ for the aqueous dispersion of the technical HAP-i and to a value of about $+5 \mathrm{mV}$, characteristic of the dispersion of the purified product.

\section{THE FORMATION OF}

\section{COLLAGEN-CALCIUM-PHOSPHATE BIOCOMPOSITES}

At the stage of production of biocomposites, calcium phosphate compounds are usually combined with both natural and artificial polymers, for example, collagen, gelatin, alginates, chitosan, polylactide, polyhydroethyl methacrylate, and others [29-33]. Of particular interest in polymeric materials is the possibility of obtaining hydrogels from them. Biocompatibility, cell adhesion, the ability to exist in the body without damaging neighboring cells are necessary criteria for the development of hydrogel biomaterials. Currently, in the manufacture of bone implants, interest is shown in technologies for combining natural and artificial polymers. This is due to the fact that such materials, by changing the properties of the biocomposite (sorption, diffusion, the ratio of hydrophobic and hydrophilic sites, etc.), make it possible to finely control the course of the basic processes of bone tissue restoration such as inflammation, dissolution, hydrolysis, enzymatic hydrolysis, and cellular biodegradation.

It has been established that after the introduction of a polymer-containing biocomposite into the animal organism, cells of various types group around it. At the first stage, loose connective tissue forms around the biocomposite, through which blood vessels and nerve fibers pass. From the blood the cellular elements of connective tissue and fibroblast cells that produce collagen enter the forming tissue. At the same time for blood as one of the main connective tissues of the body, effective circulation in the volume of the biocomposite is necessary, which can be ensured by it. porous structure.

In a simplified form, the regeneration process consists of the following stages:

1) in the area of a bone defect, a tissue clot from macrophages and fibroblasts is formed;

2) at the next stage, cells (osteoclasts) and cells (osteoblasts) are observed in the area of the defect;

3) as a result, the site is filled with fibrous tissue and bone tissue elements;

4) restoration of the periosteum, bone marrow and vascular system ultimately leads to the formation of new bone tissue.

In [34], it was noted that as a result of numerous experimental studies, high efficiency was established for the replacement of bone tissue defects and the activation of reparative osteogenesis of a biocomposite drug combining hydroxyapatite, collagen with the inclusion of antibiotics (Collapan). At the same time, the need to achieve a macropore value of the biocomposite of at least $300 \mu \mathrm{m}$ is noted, which contributes to nutrition, cellular distribution on the surface of macropores and the formation of capillaries.

In this work, we developed the basics of energy-saving technology for producing collagen-calcium-phosphate biocomposites by combining hydroxyapatite and collagen under conditions of mechano-acoustic activation of reaction mixtures. In contrast to the known methods for combining calcium-phosphate particles of a solid phase with a polymer material, in the continuation of $[35,36]$, 
biocomposites were obtained by synthesizing calcium-phosphate compounds directly in a collagen matrix.

To obtain porous calcium phosphate biocomposites, pork skin (PS) used in the food industry was used as a source of organic binders [37]. It is known [38] that upon extraction of the skin of animals, a solution of protein fractions forming fibrils is obtained. The chains of fibrils are twisted in the form of an "electric cable", and the side groups of all amino acid residues are on the outside of the molecule. Dispersion of PS was carried out in an aqueous medium to obtain a collagen sol. To obtain porous calcium-phosphate biocomposites, gelatin was also used- one of the best gel-forming agents of protein nature. Gelatin hydrosol as well as collagen with a concentration of $2 \%$ or more when cooled below $40^{\circ} \mathrm{C}$ forms stable gels. The mechanism of gelatin gel formation during the sol-gel transition is associated with the formation of a three-dimensional network structure due to hydrogen bonds. When a gelatin solution is cooled, randomly arranged helices of macromolecules change the conformation of polypeptide chains, forming a threedimensional structure with a loss of fluidity. It was found that during the enzymatic treatment of collagen-containing raw materials, high molecular weight gelatins are formed, from which strong gels are formed.

As the initial collagen-containing raw material, we used PS, fat-free with hexane, subjected to cryogenization to a particle size of $\leq 5 \mathrm{~mm}$ and blanching at a temperature of $60^{\circ}$ C. The synthesis of hydroxyapatite-collagen compositions was carried out in RPA during sequential loading of components according to the schemes: collagen-hydroxyapatite ratio, 6: 4 (HAP-C-1) and collagen-hydroxyapatite ratio, 4: 6 (HAP-C-2).
The immobilization of hydroxyapatite on the collagen matrix leads to the enlargement of the particles of the dispersed phase. So, unlike hydroxyapatite, formed in the absence of collagen having an average particle diameter of about $20 \mathrm{~nm}$, particles of the HAP-C- 1 composition have an average diameter of about $680 \mathrm{~nm}$.

The IR spectrum of HAP-C-1 pulp has a strong absorption band of $1332 \mathrm{~cm}^{-1}$, associated with the presence of ammonium nitrate in the impurity system. The composition of HAP-C- 1 was purified from ammonium nitrate by sequential washing of the precipitate with distilled water. The multiple decantation leads to a HAP-C-1 composition, according to spectral data, excluding the presence of ammonium nitrate in the composition.

The purification of the HAP-C-2 composition from ammonium nitrate was carried out using the settling method with draining the liquid and sequential washing of the precipitate with distilled water. Multiple decantation leads to a HAP-C-2 composition, according to spectral data, excluding the presence of ammonium nitrate in the composition. The resulting collagenhydroxyapatite compositions (HAP-C-1, HAP-C-2) were used to form porous medical materials.

\section{THE FORMATION OF POROUS MATERIALS BASED ON COLLAGEN-CALCIUM-PHOSPHATE COMPOSITIONS.}

Porous biomaterials are necessary for the effective interaction of implants with tissues in living systems. For all threedimensional porous biomaterials (scaffolds) participating in the cell growth stage, it is important that their surface promotes adhesion, cell fixing and their migration 
in the porous structure. New approaches developed in the work on the formation of porous biocomposites using the 3D printing technique and microwave radiation have allowed the formation of porous samples of biocomposites with different pore structures. The advantages of using porous materials for biomedical purposes based on natural and synthetic polymers are also associated with the ability to regulate the functional properties of the synthesized materials through the immobilization of enzymes, proteins, amino acids, and other natural substances [39].

The introduction into the defective areas of bone tissue of biocomposites, which include stem cells, can also be carried out using porous biocomposites.

When creating porous bone-substituting materials the biocompatible and biodegradable polymers are used, for which various methods of forming a porous structure are being developed. So, porous biocomposites are made using the following methods: 1 ) freeze drying; 2) microwave drying; 3) the use of devices with fibers (utility models); 4) the use of gas-releasing additives in the composition (porophores); 5) the formation of porous biocomposites in supercritical carbon dioxide; 6) the construction of porous biomaterials by $3 \mathrm{D}$ printing.

In the work some methods for the formation of porous collagen-calciumphosphate composites were considered. The ability of the synthesized HAP and HAP-C to form plastic pasty compositions as a result of centrifugation and removal of excess water was used. Centrifugation was carried out on an "Allegro 64R, Beckman" centrifuge in the mode of $6000 \mathrm{rpm}$ for $15-20 \mathrm{~min}$ at $10^{\circ} \mathrm{C}$. After centrifugation, hydroxyapatite concentrates were placed in special forms for the manufacture of porous biocomposites. The volumetric porous collagen calcium-phosphate biocomposites obtained by the developed methods of formation were used in models of orthopedics and traumatology to replace bone tissue defects in living systems [40].

\subsection{The FORMation of POROUS COLlagen-} CALCIUM-PHOSPHATE BIOCOMPOSITES BY FREEZE DRYING

Samples of porous composites (Fig. 2) were formed by lyophilic drying of collagencalcium-phosphate sols obtained according to the developed method. Additional cross linking was carried out with glutar aldehyde. Drying was carried out in a freeze dryer "Martin Christ Gamma 1-16 LSCplus" at a condenser temperature of $-55^{\circ} \mathrm{C}$.

After freeze drying, depending on the water content in the collagen component, porous samples with a density of $0.15-0.2 \mathrm{~g} / \mathrm{cm}^{3}$ are obtained. Using the method of reference contact porometry [41] to determine the weight of samples processed under vacuum with an organic liquid-octane, it was determined that the bulk of the pores for the HAP-C-1 biocomposite are in sizes from $10 \mu \mathrm{m}$ to 100 $\mu \mathrm{m}$. In this case, pores of approximately 60 $\mu \mathrm{m}$ are dominant.

When comparing collagen-calciumphosphate biocomposites with pure hydroxyapatite (without a binder organic component), it was found that the pore surface size depends on the ratio of the mineral and organic components of the

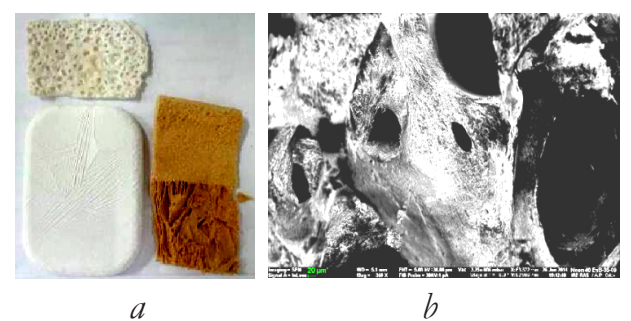

Fig. 2. Samples of collagen-calcium phosphate biocomposites after freeze drying (a), micrograph of pores of the biocomposite sample (b), scale - $20 \mu \mathrm{m}$. 
composite and significantly decreases with an increase in the content of the organic component. So, the xerogel of pure HAP2 is characterized by a pore area of about $616 \mathrm{~m}^{2} / \mathrm{g}$, and for the collagen-calciumphosphate composition this value decreases to $27 \mathrm{~m}^{2} / \mathrm{g}$, which is due to the blocking of pores by the organic component.

\subsection{THE FORMATION OF POROUS}

\section{BIOCOMPOSITES BY GRANULATION AND FIBER FORMATION}

The method of filling forms with granules or fiber is associated with percolation models. Between the granules and the fibers, physiological fluids flow that provide the conditions for the growth of cells. The production of granules and fibers in the work was carried out from flowing collagen-calcium-phosphate paste. When forming fibers, sodium alginate was additionally introduced into the composition. Extrusion of the mixture composition during the formation of fibers was carried out using a peristaltic pump in a solution of calcium chloride. The resulting granules and fiber were subsequently subjected to freeze-drying and a tissue-engineering structure using solutions of biodegradable polymers was assembled from them.

In Fig. 3 presents images of granules and fibers from which the tissue-engineering structure is assembled.

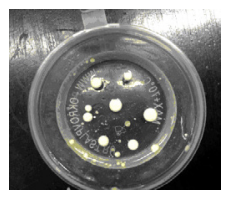

$a$

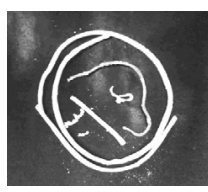

b
Fig. 3. Granules made by dispersing a suspension of HAP-C-2 in liquid paraffin (a), HAP-C-2 fibers formed in a solution of calcium chloride (b). The area is a $4 \times 4 \mathrm{~cm}$ in the photo.

\subsection{THE FORMATION OF POROUS}

\section{BIOCOMPOSITES USING SPECIAL FORMS AND} DEVICES

To form biocomposites with a large pore size of 100 to $300 \mu \mathrm{m}$, special forms and devices have been developed and manufactured [42]. The device (Fig. $4 a$ ) for the formation of a porous bone composite consists of a hollow cuvette (1) made with the possibility of filling with a biocomposite mass (2) and porositydefining embedded fibers (3), which are fixed in through holes (4) made in the walls ditches. After filling with a biocomposite mass, drying and removing fibers, a composite is obtained with a given through porosity and a given fiber distribution. Fibers are selected from the group including textile, polymer, metal fibers, including biodegradable materials with a diameter of 100-500 microns.

A cuvette for filling with a biocomposite is made of polymethylmethacrylate, Teflon or metal if it is necessary to heat the binder component or to initiate the polymerization process. A cuvette for filling with a biocomposite mass can also be made in the form of a tube (Fig. 4b) from an elastic polymer, mainly rubber, and the insertion of embedded fibers (3) is carried out through the through holes in its walls formed by piercing with a needle and thread. The photos of the surface sections

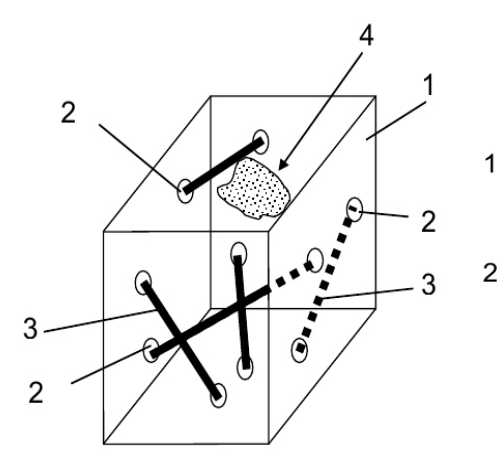

$a$

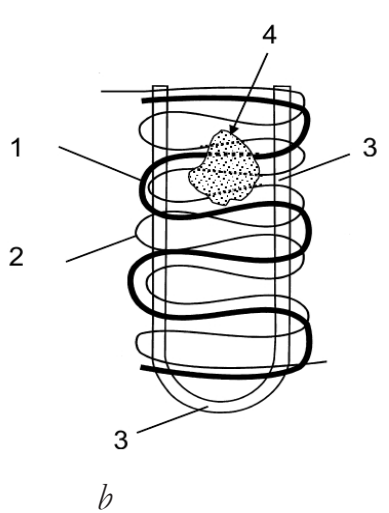

Fig. 4. Devices for the formation of biocomposites with through porosity. 

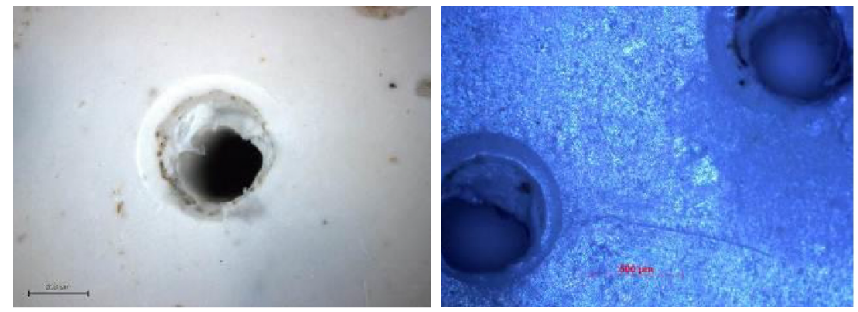

Fig. 5. Sections of the surface of the composite with through pores.

of the collagen calcium phosphate composite with through pores are shown in Fig. 5.

Such methods can be used both for the manufacture of biocompositions from natural polymers, as well as mixed compositions from natural and synthetic polymers. Mixing aqueous pasty compositions with natural polymers and pasty synthetic polymers in organic solvents under the conditions of ultrasonic dispersion of mixtures made it possible to obtain pasty mixtures and extruding from the syringe to form biocomposites in the form of a lattice with a window of the order of $0.3-0.3 \mathrm{~mm}$ (Fig. 6b).

\subsection{THE FORMATION OF POROUS BIOCOMPOSITES BY MICROWAVE HEATING}

The use of microwave radiation to remove liquid phases from biocomposite compositions is promising especially in the conditions of formation of mixed compositions from natural and synthetic polymers. Biocomposites containing water, polar solvents, electrically conductive particles, when interacting with

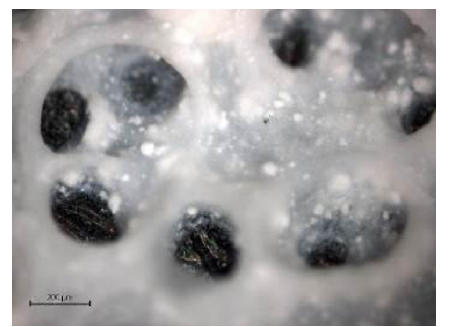

$a$

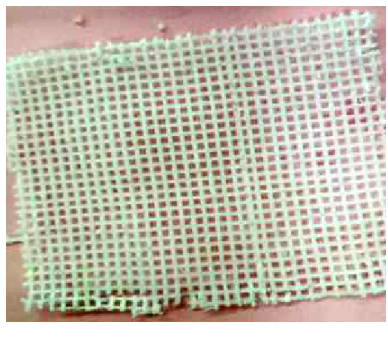

b
Fig. 6. a) Pores in the polylactide sample with bydroxyapatite particles were formed after combining the components and drying on a rotary evaporator; b) A sample from the composition of sodium alginate - HAP-2 in the form of a lattice, made in a special form. microwave radiation (microwave range) are intensively heated. As a result, liquid substances moving into the gas phase are removed from the biocomposite and the porous structure of the material is formed [43].

The interaction of electromagnetic radiation (EMR) with samples of materials is characterized by reflection coefficients $(R)$, absorption $(Q)$, transmission $(T)$. The values of $R, Q, T$ are determined by the complex values of the dielectric and magnetic permeabilities of the samples of materials, the wavelength $(\lambda)$ of the radiation and the thickness of the irradiated material (d). Model experiments with materials of various nature (intercalated graphites, fumed paper, liquids) showed that for effective interaction with electromagnetic radiation, a certain ratio of the specific volume resistance of the materials $\left(\rho_{v}\right)$, the thickness of the material (layer $d$ ) and the location of the material on the dielectric substrate (with the value dielectric constant $\varepsilon$ ). The balance of all parts of the energy determines the heating conditions.

To remove the liquid phases from the collagen-hydroxyapatite composite, a microwave oven was used (frequency $2.45 \mathrm{GHz}$, power $800 \mathrm{~W}$ ). The samples of biocomposites were made by applying a paste-like complex of the studied components on a dielectric Teflon substrate with followed by drying under the influence of radiation from a microwave oven.

It was found that the drying process in the mode of sequential heating of the collagenhydroxyapatite composition for 15-20 seconds does not lead to strong heating of the samples and the development of destructive processes. Raman spectra (Raman spectra) of collagenhydroxyapatite samples are lyophilically dried and dried under the influence of microwave radiation. The comparison of porometric parameters in the pore region of more than $10 \mu \mathrm{m}$ of samples of biocomposites dried 
freeze-dried and under the influence of microwave radiation also did not reveal obvious differences.

Microwave radiation was also used in the preparation of complex compositions including, in addition to collagenhydroxyapatite, additional biodegradable polymers. In this case, an aqueous suspension of collagen-calcium phosphate under the influence of ultrasound with a frequency of $22 \mathrm{kHz}$ and a generated emitter power of 100 W was mixed with a biodegradable polymer in an organic solvent. The formation of porous biocomposites was carried out by layer-by-layer deposition of compositions on a dielectric substrate and the removal of liquid components under the influence of microwave radiation. The amount of the polymer component $M$ (g) required to ensure optimal film formation on the hydroxyapatite particles was estimated taking into account dry hydroxyapatite $(m, g)$, specific surface area of hydroxyapatite powder $\left(S \mathrm{~cm}^{2} / \mathrm{g}\right)$, polymer density, $(\varrho, \mathrm{g} / \mathrm{cm} 3)$ and the thickness of the polymer layer on the surface of the powder particles $(h, \mathrm{~cm})$.

Noteworthy the biocomposite obtained on the basis of 2-hydroxyethyl methacrylate (HEMA) and HAP using microwave radiation. For this, HAP-2 paste with a water content of $12 \%$ in an amount of $19.8 \mathrm{~g}$ was mixed using a UZDN-1 low-frequency ultrasonic disperser (emitter frequency $15 \mathrm{kHz}$ ) with $5.1 \mathrm{~g}$ HEMA. The weight ratio of GEMAHAP (in terms of dry HAP, 1:3.5). GEMAHAP-2 paste was exposed to: drying by means of microwave radiation. When potassium persulfate is introduced into the paste, followed by microwave heating and drying, the polymerization process takes place and solid white organomineral compositions are formed.

As a result of studies, it was found that when additives are added to the composition of pasty compositions that affect the electrical conductivity of the compositions, it is possible to control the rate of release of gaseous components, and thereby affect the porous structure of biomaterials. The introduction of fibrous additives can also significantly affect the distribution of the porous structure in the biomaterial.

The results of studies on the formation of a porous structure in samples of biopolymers have shown that the use of thermal and microwave (microwave) methods for removing the liquid phase is most effective for samples containing water. Therefore, the manufacture of porous biomaterials through the stage of creating aqueous emulsions from filmforming biocompatible polymers with calcium phosphate compounds is promising for the formation of porous biomaterials. It is established that a combination of thermal and microwave heating in a polymer matrix gives rise to a developed pore structure. During thermal heating, thermoplastic polymers become viscous, and the exit of gas-forming components from the liquid phase forms through pores in the material and large pores.

\section{FABRICATION OF TISSUE ENGINEERING STRUCTURES.}

For the manufacture of tissue-engineering structures, biocompositions from natural and synthetic polymers in the form of pastes, thermoplastic rods, and nonwoven fibrous materials were prepared. This approach made it possible to construct tissue-engineering structures with various combinations of the initial compositions, which are constituent structures and are themselves samples of materials for replacing bone tissue defects. Paste-like calcium phosphate compositions were prepared by mixing synthesized hydroxyapatite particles with suspensions of collagen, gelatin, sodium alginate and synthesizing hydroxyapatite particles directly in 
polymer suspensions. Techniques for making pastes include the steps of synthesizing hydroxyapatite particles, ultrasonic dispersion, and the centrifugation step to obtain a pastelike consistency of the compositions.

Using indenter immersion methods under load in samples of calcium phosphate pastes, it was determined that the viscosity of the compositions is a characteristic of the plastic properties of pastes. Measurements of calcium phosphate paste samples were carried out according to the method of immersing an indenter in a sample under load. After application of the load, a creep process develops in the sample, associated with the development of irreversible deformation. The viscosity of the composition is $0.44 \mathrm{MPa}$. An increase in the concentration of hydroxyapatite particles led to an increase in the elastic properties of the composition (when the ratio of hydroxyapatite particles to HAP-C collagen was 6:4). When a $5 \%$ solution of glutaraldehyde is added to collagen-hydroxyapatite concentrate, and a $5-15 \%$ solution of calcium chloride is added to the composition of sodium alginate, the material samples acquire elastic properties and the strength of the samples increases due to the formation of crosslinks between polymer macromolecules.

The porous collagen samples of calcium phosphate compositions are made by filling pastes with molds and drying by freeze drying and microwave heating. As a result of drying the porous samples were obtained in the form of plates with a density of $0.15-0.2 \mathrm{~g} / \mathrm{cm}^{3}$. Using the method of reference contact porometry, it was determined that the majority of the pores are in sizes from $10 \mu \mathrm{m}$ to $100 \mu \mathrm{m}$. The porous samples in the form of plates are also made by mixing particles of hydroxyapatite with suspensions of sodium alginate.

After filling the forms of various designs with pastes and drying the porous samples of various kinds were obtained. When mixing sodium alginate ( $\mathrm{Na}$ alginate) and hydroxyapatite particles, in which a uniform, necessary consistency paste is formed $(65 \%$ ( $2 \%$ $\mathrm{Na}$ alginate solution) and 35\% hydroxyapatite powder (HAP). The resulting mixture (HAP and $\mathrm{Na}$ alginate) was carefully dispersed with using ultrasonic exposure by a low-frequency ultrasound generator with a frequency of 22 $\mathrm{kHz}$ for 5-10 minutes.

It has been found that it is possible to combine collagen calcium phosphate concentrates with solutions of synthetic polymers to produce pastes from a mixture of natural and synthetic polymers. A mixture of collagen calcium phosphate paste with a solution of polylactide (in a ratio of 1:1, by weight) was carried out under ultrasonic dispersion for 5 minutes. The formation of mixed plastic compositions from natural and synthetic polymers is a promising area of tissue engineering. Using various methods of forming a porous structure, tissue engineering structures of varying complexity can be manufactured for biomedical applications.

The results of comparative tests of the strength properties of biocomposites based on natural and synthetic polymers have shown that the combination of polymers of different nature leads to an increase in the strength properties of biocomposites and a change in the time of their biodegradation in living systems.

Ufter saturated with water the samples acquire elastic properties. The highest strength $(80 \mathrm{MPa})$ and the lowest tensile deformation $(25 \%)$ have samples based on polyacrylamide gel (PAAG). Collagen based compositions have the highest tensile deformation (65\%), but their strength $(2 \mathrm{MPa})$ is low. With an increase in the thickness of the polymer layer of synthetic biodegradable polymers on the surface of a porous collagen of a calcium-phosphate 
sample, strength characteristics increase, and the biodegradation time also changes.

Synthetic biodegradable polymers: polylactide- PLA (brand 4032D Nature Works LLC (LD, L)), poly-3-hydroxybutyrate - PHB obtained by microbiological synthesis (BIOMER, Germany) and polycaprolactonePCL ("ADALIK" Ltd.), relate to a class of thermoplastic polymers and were used in the work to build tissue-engineering structures. To use thermoplastic polymers in $3 D$ printing technologies, it is necessary to produce rods of a given thickness and strength. It follows from the experimental data that the polylactide sample has the highest strength, and the introduction of hydroxyapatite particles (20 mass\%) into the synthetic polymer (PHB) leads to a decrease in strength characteristics.

Studies of the thermophysical and strength properties of thermoplastic biodegradable polymers are necessary for constructing tissueengineering structures using $3 D$ printing. Therefore, comparative studies of polymer samples, polymer blends, and composite material samples were carried out using the TGA, TMA, DMA, DSC methods.

The processes of heating and cooling during extrusion by the method of $3 D$ printing affect the size of the fibers, the shape and size of the cells during the construction of cellular threedimensional structures (Fig. 7). The results of measurements of the characteristics of polymer samples by the DSC method showed

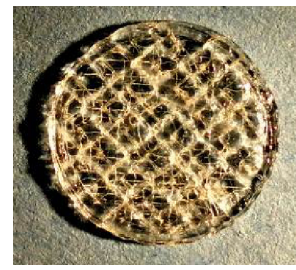

a

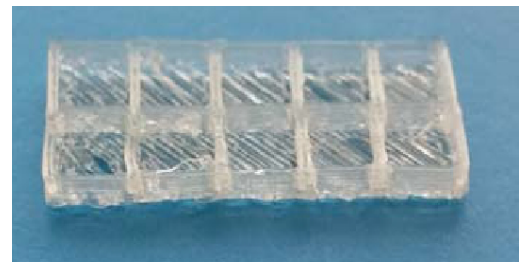

b
Fig. 7. Samples of tissue-engineering structures made of polylactide. a) the disk with cells from a polylactide bar, built according to 3D technology; b) the sample in the form of a pencil case, constructed of polylactide by $3 D$ printing. that, in the heating-cooling mode, samples from PHB do not exhibit thermal stability compared to PLA. PHB is characterized by a change in crystalline phases with conversion to an amorphous state. The spreading of the thermoplastic material leads to an increase in the thickness of the samples in the manufacture of rods. A change in the thermal stability of PHB samples occurs when the polymer is mixed with hydroxyapatite particles.

The technological process for the manufacture of rods from thermoplastic polymers and their mixtures with natural polymers was carried out in two stages. At the first stage, using the IIRT-AM thermoplastics yield index meter, thermoplastics powders were poured into IIRT-AM, heated to the melting temperature, which was determined by the DSC method. After holding for 1 minute, the material was extruded from the chamber through a capillary with a diameter of $2.08 \mathrm{~mm}$. The first stage was used to assess the feasibility of manufacturing polymer rods from new polymer combinations. The second stage was carried out in the manufacture of calibrated rods in sufficient quantities to work with a 3D printer. The production of polylactidebased rods was carried out by melt extrusion on an extrusion line manufactured by firm "Gottfert".

A mixture of polymers was obtained by mixing 7\% solutions of PLA polymers with PHB in a ratio of 1:1 and drying. Using a melt extrusion method on an extrusion line, a bar of a given diameter $(1.75 \pm 0.05 \mathrm{~mm})$ and length was manufactured.

At the IIRT-AM laboratory unit, rods were made from a mixture of $\mathrm{PHB}$ with particles of hydroxyapatite (HAP). The composition for the manufacture of the rod consisted of domestic polyhydroxybutyrate (PHB) obtained from the chloroform clarified biomass extract Methylobacterium extorquens G-10 (weight 
$18 \mathrm{~g})$, (Pushchino, Institute of Microbiology RAS) in the form of particles of size $0.5-2 \mathrm{~mm}$ and particles of hydroxyapatite in the form of a finely divided powder.

Another approach to the manufacture of the rod was to mix the polymer with hydroxyapatite particles. The manufacture of the rod from the PHB-HAP composition with a $20 \%$ mass fraction of hydroxyapatite particles was carried out after preliminary grinding of PHB particles in an IP-30 mill and mixing with HAP particles. The filler leads to a decrease in the fluidity of the polymer melt, and the forcing of the composite melt was carried out at a temperature of $180^{\circ} \mathrm{C}$.

A new approach for mixing PHB with hydroxyapatite particles was to create an aqueous suspension of PHB by mechanoacoustic treatment of the suspension in RPA. Then, in the PHB suspension, the reaction of the formation of HAP particles was carried out according to the reaction between calcium monophosphate hydrate and calcium hydroxide (by analogy with the synthesis of collagen calcium phosphate compositions). The mechano-acoustic treatment of the PHBHAP composition in water led to the formation of synthesis products in the form of a lower sediment layer, an upper layer in the form of foam and an intermediate layer of a suspension of nanoparticles. As a result of centrifugation of the precipitate, the product of the paste-like composition PHB / HAP was obtained. Using the TGA and DSC methods, it was found that the ratio of organic and inorganic components in the sediment is $80: 20 \mathrm{wt} . \%$, And the DSC dependence confirms the role of the influence of hydroxyapatite particles on the thermal stability of the composition.

In contrast to the synthetic polymers PLA, PHB, of which rods and extruded films were made at temperatures above $170^{\circ} \mathrm{C}$, polycaprolactone (PCL) rods were produced at extrusion temperatures over the extruder zones $60-80^{\circ} \mathrm{C}$. A calibrated bar with a diameter of 1.7-1.8 $\mathrm{mm}$ was obtained on the extrusion line. The PCL melt flow rate, measured on an IIRT-AM device at $100^{\circ} \mathrm{C}, 2.16 \mathrm{~kg}$ was: 15 $\mathrm{g} / 10 \mathrm{~min}$; at $80^{\circ} \mathrm{C}-7 \mathrm{~g} / 10 \mathrm{~min}$ and at $60^{\circ} \mathrm{C}$ $2.5 \mathrm{~g} / 10 \mathrm{~min}$. For maxillofacial surgery interest in polycaprolactone is due to the ability to produce samples of materials of specialized structures at temperatures of $60-80^{\circ} \mathrm{C}$.

The results of the manufacture of thermoplastic rods for the $3 D$ printing technique showed the need to develop polymer compositions with the necessary flow properties of polymer melts. Thus the process of constructing tissue-engineering structures is associated with the improvement of $3 D$ printing technology. The development of a temperature controlled $3 D$ printing technique, the use of UV, IR, and microwave radiation techniques when forming products of complex architecture by $3 D$ printing can change the polymerization rate and form a porous structure in the samples.

The methods for the formation of porous polymer composites presented in this work allow the production of porous biocomposites with various architectures. The formation of mixed compositions from natural and synthetic polymers with inorganic and organic compounds allows to design a wide range of biomaterials of varying complexity. A new approach to the mixing of polymers of various nature is implemented under conditions of ultrasonic dispersion of solutions of biodegradable polymers in chloroform with colloidal aqueous suspensions and thermostimulated microwave heating.

Non-woven porous films were made by the method of electroforming of fibers (EFF) from solutions of biodegradable polymers (PHB, PLA, PCL). 


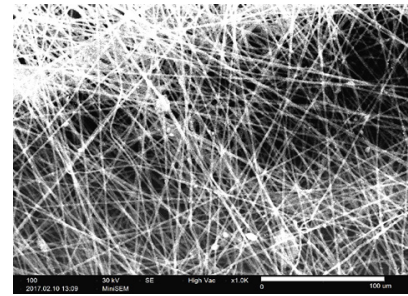

$a$

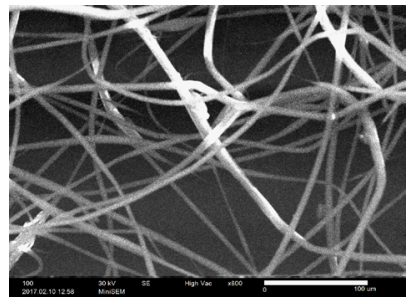

b
Fig. 8. Electron microscopy images of non-woven samples obtained by the method (EPI) from solutions of PHB a) and PLA b). Scale - 100 microns.

Fig. 8 shows electron microscopy images of nonwoven samples obtained by the EPI method from PHB and PLA solutions. The synthesis of nonwoven samples of materials from polymer solutions with inorganic and organic components was carried out under conditions of ultrasonic and mechanicalacoustic dispersion. The creation of multilayer samples of nonwoven materials with a different combination of layers and the construction of structures on samples of nonwoven materials using $3 D$ printing made it possible to create porous structures with controlled porosity and bioresorption time.

The methods of formation of a porous structure in polymer composites developed in the work indicate the need to combine various methods to achieve a branched porous structure and the required pore sizes in biomaterials. The combination of samples of materials obtained by $3 D$ printing and EPI is a promising direction in the manufacture of porous three-dimensional frame structures.

\section{METHODS OF IMPLANTING POLYMER SAMPLES INTO A BONE DEFECT.}

Studies of the effectiveness of calciumphosphate biomaterials based on natural and synthetic polymers in traumatology and orthopedics were carried out using the method of implantation of samples into a skull bone defect in vivo. The implantation technique included: incision of the prepared skin up to
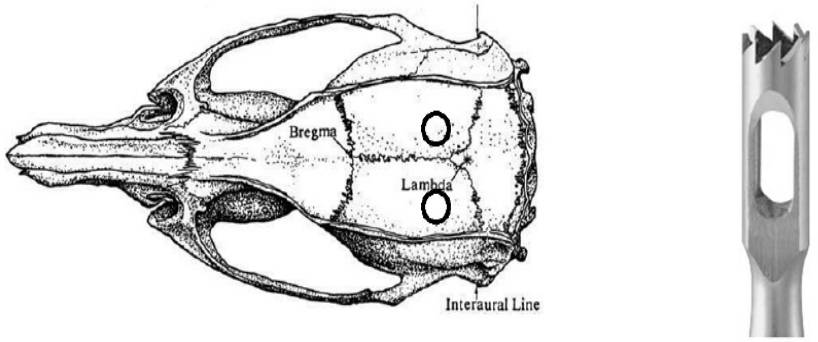

Fig. 9. Scheme for applying defects $(3.5 \mathrm{~mm})$ in the parietal bones of a rat with a round mill.

$2 \mathrm{~cm}$ and atraumatic dilution of soft tissues to the parietal bones, then two holes were formed in the bones of the skull with a round cutter with a diameter of $3.5 \mathrm{~mm}$ (Fig. 9).

The defect was closed with a prepared collagen calcium phosphate sample (KHA matrix) in this model and the reactions at the border of the graft and bone tissue were studied. The graft mineralization process was also evaluated. For this purpose, computed tomography and histological preparations of the skull bones were used.

In the preparations of the experimental group on the 60th day the filling of the defect area with fibrous connective tissue of varying degrees of density was observed. The study of the toxicity of the KHA matrix was carried out on a fibroblast culture. The surface of the sample contributed to good spreading and fixation of cells. Attached fibroblasts on the material were alive. The staining with fluorescent nuclear probes (Hoechst 33342) after 48 hours after plating of cells on the material showed their complete survival. Moreover, among them cells in anaphase and metaphase state were revealed, which directly indicates cell growth on a sample of material.

The developed porous tissue-engineering construction- the KHA matrix, consisting of collagen and hydroxyapatite materials that are biologically natural for bone tissue, is close to the native bone in percentage. The production technology of such structures allows the 
inclusion of drugs in its composition, depending on the specific clinical task. The structure and physicochemical properties of the developed bone implant provide it with high adhesive properties for fibroblast cells. This contributes to the activation of reparative processes in bone defects, without interfering with natural osteohistogenesis.

The use of the developed design with the inclusion of an antibiotic in it makes it possible to eliminate the purulent-destructive inflammatory process in the model of posttraumatic osteomyelitis with restoration of bone tissue. The developed methods for studying porous collagen-calcium-phosphate matrices were also used in the study of porous calcium-phosphate compositions based on other natural and synthetic polymers in the replacement of bone defects.

As a result of the synthesis of hydroxyapatite in a suspension of PHB, paste PHB/HAP with a $20 \%$ content of hydroxyapatite particles was obtained. Films 100-200 $\mu \mathrm{m}$ thick, rods for 3D printing, and a 2-layer fabric engineering design based on the porous non-woven material PHB obtained by EPI and paste - PHB/HAP were made from these compositions. The paste was applied to a nonwoven sample of PHB material and dried under the influence of microwave radiation. During subcutaneous implantation of the fabricated material samples, their biocompatibility and the absence of inflammatory reactions in the tissues were noted. The results obtained allowed us to proceed to the design of complex tissueengineering structures by $3 D$ printing in the form of volumetric cellular structures and filling their calcium with phosphate pastes. The method of $3 D$ printing made porous cellular samples, it is planned to fill the cells with calcium phosphate pastes containing morphogenetic protein and other bioactive materials. Biomedical testing of samples of biocomposites in living systems allows you to adjust the methods, composition and conditions for the manufacture of structures of complex architecture. The manufacture of biocomposites with the introduction of biological components from living organisms into them will stimulate the process of osteogenesis and restore the process of replacing a bone defect.

\section{PRODUCTION OF BONE SUBSTITUTE MATERIALS USING THE 3D PRINTING METHOD.}

The development of frame-type implants is currently an important area of tissue engineering. With this construction, a framework made of a thermoplastic polymer plays the role of mechanical support, and is filled with biomaterial that acts as an extracellular matrix.

The development of new methods and approaches for $3 \mathrm{D}$ printing of bone implants, which, after being introduced into the body, can be reconstructed into living bone tissue, for maxillofacial surgery and dentistry are the most popular and can be implemented in the first place. Jaw defects resulting from inflammatory and tumor processes, traumatic injuries, and tooth extraction make it difficult to rehabilitate patients and prosthetics.

Currently, biomaterials are used to replace jaw defects in the form of chips, blocks and gels, which, however, are not able to restore the shape and structure of lost bone. These limitations can be overcome with the help of new approaches to computer modeling and combined $3 D$ printing methods, which allow creating bone implants close in structure and biological properties to living bone tissue.

As a layout, a 3D model of a bone with a defect was constructed using computed tomography data, using the example of the lower jaw. For this the ViSurgery program 
was used. By software, a model of a bone implant was formed, repeating the contours of the defect and replenishing its volume with the formation of the internal structure of the implant in the form of a beam threedimensional structure. Fig. 10 shows the appearance of the $3 D$ model of the lower jaw after it is divided into regular cells. The cortical (external) frame of the implant was printed using a polylactide rod. The formation of a spongy (internal) structure of the bone implant and jaw model was performed with hydroxyapatite paste.

The development of a lattice structure will allow us to split the $3 D$ model of the implant into lattices (Fig. 10), which in turn repeat the individual implant geometry to restore the bone defect in the patient and allow the strength characteristics of the implant to be preserved after transplantation. At the same time, the space between the beams is communicated throughout the implant, which will not impede the growth of vessels deep into the implant and limit regeneration, simulating the natural structure of bone tissue.

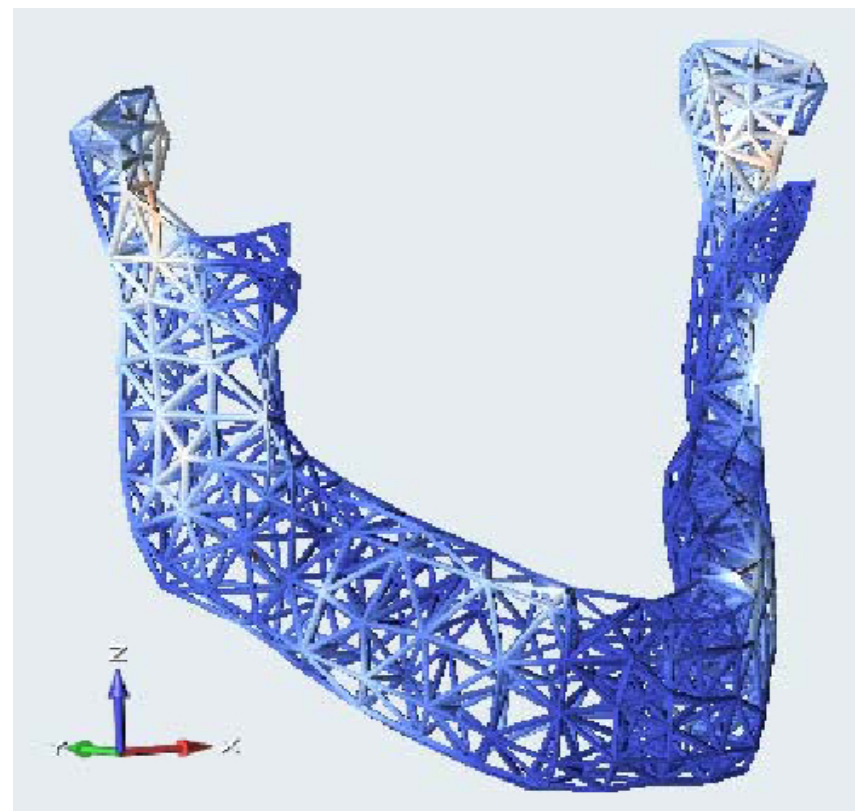

Fig. 10. The lattice structure of the lower jaw, modeled in the Inspire software package.
The development of a $3 D$ printer for combined printing with biocompatible polymers (polylactide, polyoxybutyrate, polyglycolide) by the method of layer-by-layer deposition (FFM) and pastes based on natural and synthetic components, the method of direct extrusion is an innovative and highly sought-after approach to solving the problem of timing and quality of bone restoration defects.

In the work, pastes based on hydroxyapatite and sodium alginate (HAP-AN) were used as biomaterials filling the framework of a thermoplastic polymer. HAP-AN paste was used in the preparation of compositions containing biopolymers with viscous-flowing properties and suitable for the construction of implants using the $3 D$ printing method. The implants were constructed in layers. Various combinations of mixing the components of the compositions and the construction of product layers were used. At the same time, a new approach was implemented in the work, associated with the use of nonwoven polymeric materials as a substrate for constructing a polymer skeleton. Non-woven polymeric materials obtained by electrofiber forming (EFF). Forming was carried out on a substrate of nonwoven polypropylene material using a $7 \%$ chloroform solution of polyhydroxybutyrate (PHB). The electrical conductivity of the solution was about $9 \mu \mathrm{S} /$ $\mathrm{cm}$. The capillary diameter is $0.1 \mathrm{~mm}$.

Electroforming of nonwoven fibrous materials from PHB was carried out with the aim of manufacturing

- substrates for further layering of calciumphosphate compositions and construction of implant structures using a 3D printer; -for electroforming non-woven fibrous materials with dosage forms. 
So, on a non-woven material from PHB by 3D printing a polylactide (PLA) framework was constructed, which was then filled with a paste-like water composition HAP-AN. For the study of the behavior of biomaterials in living systems, samples of various architectures were made.

In Fig. 11 shows PLA disks located on a PHB membrane constructed using 3D printing technology. The development of such structures from two polymers, one of which is of the membrane type, opens up new possibilities in the production of artificial bone substitute materials.

The samples of mesh (lattice) architecture seem to be the most promising for the replacement of bone defects, as it provides greater access to cells to three-dimensional porous structures during the formation of new tissue.

In the work, compositions were developed, including HAP and biodegradable polymers, suitable for the construction of implants using $3 D$ printing technology. The combination of HAP with polymers was carried out under conditions of ultrasonic dispersion of mixtures using chloroform solutions of PHB, PLA, and aqueous suspensions of HAP. From compositions comprising HAP and biodegradable polymers, the corresponding fibrous non-woven materials were obtained by electroforming. The conditions of electrostatic forming of fibrous nonwoven materials do

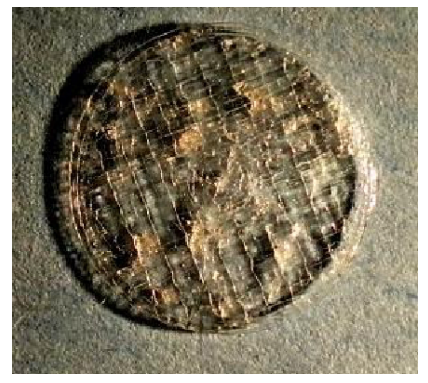

$a$

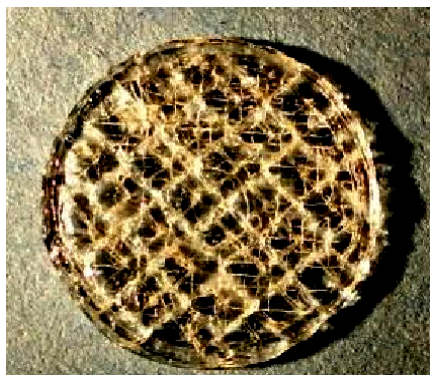

$b$
Fig. 11. The disks from PLA on the PHB (a, b), built using $3 D$ technology. not significantly affect the chemical nature of the starting biopolymers. This, in particular, is indicated by the results of IR spectroscopy. Spectra of reflection (not detecting significant differences among themselves) of PLA films obtained by pressing and electroforming.

Part of the polymer-containing compositions before doping was doped with the endoxan dosage form. The idea of creating fibrous non-woven materials with dosage forms is associated with the need to obtain implants with a prolonged ability to suppress bone tissue neoplasms.

Using $3 D$ printing, samples from synthetic polymers were fabricated in a layer-by-layer manner on fabric-based non-woven samples from the corresponding polymers. On a nonwoven fibrous material obtained by the EFF method from solutions of biodegradable polymers, a tissue-engineering cellular structure with a predetermined pore size (100-500 $\mu \mathrm{m})$ is formed by $3 D$ printing, which is filled with calcium phosphate pastes containing natural polymers and necessary components. After assembly, the structure is dried by thermostimulated microwave heating.

To determine the changes in biocomposites that occur in living organisms over time, a series of samples were prepared based on biodegradable polymers and calcium phosphate pastes.

It was established by electronic, atomic force, and acoustic microscopy that polylactide wafers aged for 1-3 months in living organisms undergo changes. As a result of biodegradation, the average height of the microrelief decreases.

During histological examination of bone tissue samples containing a polymer threedimensional structure, it was found that bridges and the outer membrane of the structure, around which the connective and bone tissue 
of the regenerate are located, are clearly constructed among the bone regenerate.

Contact of bioimplant with bone tissue occurred without a layer of connective tissue. Regenerative type connective tissue with signs of focal osteogenesis was in contact with the bioimplant without visible cellular reactions characteristic of inflammation. Reticulofibrotic bone tissue rested on a bioimplant and spread along it. Osteoblast precursors evicted from immature connective tissue cells formed an osteoid in the immediate vicinity of the structure without significant signs of inhibition of reparative osteogenesis. A targeted study of the contact area of the connective tissue of the regenerative type and the material of the three-dimensional structure did not reveal a pronounced macrophage and inflammatory infiltration of it. The fibers of connective tissue penetrated into the gaps of the material, which indicates in favor of its hydrolytic dissolution.

A histological investigation of tissue samples containing a three-dimensional plastic structure created by the three-dimensional printing method revealed that the bioimplant from which the structure is produced has good supporting functions for connective, bone, and granulation tissue. The bioimplant does not cause severe inflammatory infiltration by lymphocytes, neutrophils and giant cells of foreign bodies. The bioimplant resorption probably occurs by hydrolysis, the metabolites released during this do not negatively affect reparative osteogenesis.

\section{CONCLUSION}

Thus, the synthesis of nanosized hydroxyapatite by the exchange reaction between diammonium phosphate and calcium nitrate under conditions of mechano-acoustic processing of the reaction mixture was developed. The methods for purifying hydroxyapatite from by-products are proposed. By dispersing raw materials of animal origin, a protein hydrosol was obtained in the medium of which hydroxyapatite was synthesized and a collagen-calcium-phosphate composite was obtained. The methods of forming porous collagen-calcium-phosphate composites, including the action of microwave radiation, are considered.

It is shown that based on the developed biocompositions: calcium phosphate pastes, compositions from thermoplastic biodegradable polymers, non-woven fibrous materials, fabric-engineering constructions with an adjustable architecture can be made to solve various biomedical problems. The manufacture of biocomposites with the introduction of biological components from living organisms and drugs into their composition will stimulate the process of osteogenesis and restore the process of replacing a bone defect.

The creation of three-dimensional structures capable of performing the functions of a particular natural tissue of the body, based on a combination of cells and scaffolds (threedimensional structures, matrix, framework), as well as other factors affecting cell growth, their differentiation and organization of the extracellular matrix, is an important task of the tissue engineering [44-46].

The work was carried out with the financial support of the Russian Federal Property Fund, project 18-29-23042.

\section{REFERENCES}

1. Joint European Commission/ETN nanomedicine: roadmaps in nanomedicine towards 2020. Expert Report, 2009, p. 33.

2. Popkov AV. Biosovmestimyye implantaty v travmatologii i ortopedii (obzor literatury). Geniy ortopedii, 2014, 3:94-99 (in Russ.).

3. Nekachalov VV. Patologiya kostey $i$ sustavov. Rukovodstvo. SPb, Sotis Publ., 2000, 288 p. 
4. Avdonin PV, Tkachuk VA. Retseptory $i$ vnutrikletochnyy kal'tsiy. Moscow, Nauka Publ., 1994, 288 p.

5. Tkachuk VA. Stvolovyye kletki i regenerativnaya meditsina. Moscow, Lomonosov MSU Publ., 2014, 220 p.

6. Murayev AA, Dymnikov AB, Korotkova NL, Kobets KK, Ivanov SYU. Optimizatsiya parametra planirovaniya plasticheskikh operatsiy v chelyustno-litsevoy oblasti. Sovremennyye tekhnologii $v$ meditsine, 2013, 5(3):57-62 (in Russ.).

7. Konyshev VA. Stimulyatory $i$ ingibitory rosta organov i thaney zhivotnykh. Moscow, Meditsina Publ., 1974, 191 p.

8. Tertsi M. Genetika i zhivotnaya kletka. Moscow, Mir Publ., 1977, 291 p.

9. Neyfakh AA, Lozovskaya YeR. Geny $i$ razuitiye organizma. Moscow, Nauka Publ., 1984, 192 p.

10. Sveshnikov AA, Smotrova LA, Ovchinnikov YeN. Mekhanizmy demineralizatsii kostnoy tkani. Geniy ortopedii, 2005, 2:95-99 (in Russ.).

11. Lekishvili MV, Panasyuk AF. Novyye bioplasticheskiye materialy $\mathrm{V}$ rekonstruktivnoy khirurgii. Vestnik $\mathrm{R} A M N$, 2008, 9:33-36 (in Russ.).

12. Salai M, Brosh T, Keller N, Perelman M, Dudkiewitzet I. The effects of prolonged cryopreservation on the biomechanical properties of bone allografts: A microbiological, histological and mechanical study. Cell and TiPSue Banking, 2000, 1(1):69-73.

13. Lekishvili MV. Tekhnologii izgotovleniya kostnogo plasticheskogo materiala dlya primeneniya $\mathrm{v}$ vosstanovitel'noy khirurgii: Diss. dokt. med. nauk. Moscow, 2005.

14. Volova LT, Kirilenko AG, Uvarovskiy BB. Sposob sterilizatsii liofilizirovannykh kostnykh transplantatov. Patent RF:2156139, 1999.

15. Shchepkina EA, Kruglyakov PV, Solomin LN at all. Transplantatsiya autologichnykh mezenkhimal'nykh stvolovykh kletok na demineralizovannom kostnom matritse pri plastike lozhnykh sustavov i kostnykh defektov. Mater. III V serossiyskogo simpoziuma $s$ mezhdunarodnym uchastiyem "Aktual'nyye voprosy tkanevoy $i$ kletochnoy transplantologii». Moscow, 2007, p. 113 (in Russ.).

16. Ershov YuA, Gorshenev VN, Kosenko NV. Sposob formirovaniya kostnogo implantata. Patent RF:2206341, 2002.

17. Ershov YuA, Gorshenev VN. Kollagengidroksiapatitovyye implantaty dlya ortopedii. Materialy pervoy $V$ serossiyskoy konferentsii s uchastiyem RS. "Nanotekhnologii v onkologii-2008». Moscow, 2008, p. 127 (in Russ.).

18. Hull C. Method for production of threedimensional objects by stereolithography. US Patent: 4929402, 1990.

19. Bredt JF, Sach E, Brancazio D, Cima M, Curodeau A, Fan T. Three dimensional printing system. US Patent: 5807437, 1998.

20. Landers R, Pfister A, Hubner U, John H, Schmelzeisen R, Mulhaupt R. Fabrication of soft tissue engineering scaffolds by means of rapid prototyping techniques. J. Mater. Sci., 2002, 37(15):3107-3116.

21. Taboas JM, Maddox RD, Krebsbach $\mathrm{PH}$, Hollister SJ. Indirect solid free form fabrication of local and global porous, biomimetic and composite 3D polymerceramic scaffolds. Biomaterials, 2003, 24(1):181-194.

22. Sachlos E, Czernuszka JT. Making tissue engineering scaffolds work. Review on the application of solid freeform fabrication technology to the production of tissue 
engineering scaffolds. European Cells Materials, 2003, 5:29-40.

23. Safronova TV, Shekhirev MA, Putlyayev VI, Tret'yakov YuD. Keramicheskiye materialy na osnove gidroksiapatita, sintezirovannogo iz rastvorov, podvergayutsya vozdeystviyu. Neorganicheskiye materialy, 2007, 43(8):10051014 (in Russ.).

24. Safronova TV, Kuznetsov AV, Putlyayev VI, Veresov AG, Ivanov VK. Keramika na osnove gidroksiapatita, sintezirovannogo iz atsetata kal'tsiya i gidrofosfata natriya. Perspektivnyye materialy, 2008, 6:96-99 (in Russ.).

25. Sinitsyna OV, Veresov AG, Kovalova YeS, Kolenko YuV, Putlyayev VI, Tret'yakov YuD. Polucheniye gidroksiapatita gidrolizom $\alpha-\mathrm{Ca}_{3}\left(\mathrm{PO}_{4}\right)_{2}$. Iqvestiya Akademii nauk. Seriya kbimicheskaya. 2005, 1:78-85 (in Russ.).

26. Stevens MM. Biomaterials for bone tissue engineering. Materials Today, 2008, 11(5):18-25.

27. Sun JS, Tsuang YH, Liao CJ, Hang YS, Lin FH. The effect of sintered - dicalcium phosphate particale size on newbom wistar ratosteoblasts. Atifinal Organs, 1999, 23(4):331-338.

28. Kesel' BA, Fedorov AD, Gimushin IF, Volkov GA, Gataullin RSh, Voskoboynikov DV, Vesel'yev DA. Rotorno-pul'satsionnyy apparat (RPA). Patent RF: 2166986, 2006.

29. Kovaleva YeS, Filippo YaYu, Putlyayev VI, Tret'yakov YuD, Ivanov VK, Silkin NI, Galiullina LF, Rodionov AA, Mamin GV, Orlinskiy SB, Salakhov MKh. Biorezorbiruyemyye poroshkovyye materialy na osnove $\mathrm{Ca} 1_{0-\mathrm{x}} \mathrm{Nax}\left(\mathrm{PO}_{4}\right)_{6-}$ ${ }_{x}\left(\mathrm{CO}_{3}\right) \mathrm{x}(\mathrm{ON})_{2}$. Uchenye rapiski Kazanskogo universiteta. Seriya Estestvennye nauki, 2010, 152(1):79-98.
30. Saenger AT, Kuhs WF. Golden Book of Phase Transitions. Wroclaw, 2002, 1:1-123.

31. Nair LS, Laurencin CT. Polymers as Biomaterials for Tissue Engineering and Controlled Drug Delivery. Adv. Biochem. Engin./Biotechnol. 2006, 102:47-90.

32. Holland TA, Mikos AG. Biodegradable Polymeric Scaffolds. Improvements in Bone Tissue Engineering through Controlled Drug Delivery. Adv. Biochem. Engin./Biotechnol. 2006, 102:161-185.

33. Varghese S, Elisseeff JH. Hydrogels for Musculoskeletal Tissue Engineering. $A d v$ Polym Sci., 2006, 203:95-144.

34. Shtil'man MI. Polimery mediko-biologicheskogo nånacheniya. Moscow, Akademkniga Publ., 2006, 400 p.

35. Berchenko GN. Sinteticheskiye kal'tsiyfosfatnyye materialy $\mathrm{v}$ travmatologii i ortopedii. Sbornik rabot V sesoyuznoy nauchno-prakticheskoy konferentsii. «Primeneniye iskustvennykh kal'tsiyevo-fosfatnyk kb biomaterialov $v$ travmatologii $i$ ortopediiis. Moscow, 2010, P. 3-5 (in Russ.).

36. Gorshenev VN, Teleshev AT, Yershov YuA, Kaziyev GZ, Kolesov VV, Sklyanchuk ED. Sposob polucheniya poristogo kostnogo biokompozita. Patent RF: 2482880, 2013.

37. Gorshenev VN, Yershov YuA, Teleshev AT, Sklyanchuk ED, Prosvirin AA, Grigor'yev SA. Gidroksiapatitovyye biokompozity meditsinskogo naznacheniya. Meditsinskaya tekbnika, 2014, 1:30-32 (in Russ.).

38. GOST 32244-2013 Subprodukty myasnyye obrabotannyye. Tekhnicheskiye usloviya. URL http://docs.cntd.ru/ document/1200107178.

39. Neklyudov AD, Ivankin AN. Kollagen: polucheniye, svoystva i primeneniye. Moscow, GOU VPO MGUL Publ., 2007, 336 p. 
40. Shtil'man MI. Polimery mediko-biologicheskogo naznacheniya. Moscow, Akademkniga Publ., 2006, 400 p.

41. Prosvirin AA, Sklyanchuk ED, Gur'yev VV, Gorshenev VN, Teleshev AT, Akatov VS, Fadeyeva IS, Fadeyev RS, Shushkevich AM. Fiziko-khimicheskiye svoystva i biosovmestimost' nanostrukturirovannogo poristogo kostnogo implantata. Tekhnologii zhivykh sistem, 2013, 8:68-73 (in Russ.).

42. Vol'fkovich YuM, Sosenkin VE, Shkol'nikov YeI, Bagotskiy VS. Metod kontaktnoy etalonnoy porometrii. Dokl. AN SSSR, 1977, 232(3):603-606.

43. Gorshenev VN, Gorsheneva TD. Prisposobleniye dlya formirovaniya kostnykh biokompozitov s otkrytoy poristost'yu. Patent RF № 143634, 2014.

44. Gorshenev VN, Murayev AA, Teleshev AT, IvanovSYu. Novyye additivnyye tekhnologii formirovaniya slozhnykh kostnykh struktur. Materialy IV Mezhdistsiplinarnogo kongressa po zabolevaniyu organov golovy $i$ shei. Moscow, 2016, p. 80.

45. Tortelli F, Cancedda R. Three-dimensional cultures of osteogenic and chondrogenic cells: a-tissue engineering«approach to mimic bone and . cartilage in vitro. Eur. Cell Mater., 2009, 17:1-14.

46. Devyatkov ND, Kislov VYa, Kolesov VV, Grachev VI. Diagnostics and correction of the functional state of the human organism with the "Charm"-diagnostic complex. RENSIT, 2018, 10(2):257-268, DOI: $10.17725 /$ rensit.2018.10.257. 